AJCHE 2011, Vol. 11, No. 1, $54-59$

\title{
Methanolysis of Jatropha Gurcas L. Oil Using Conventional Heating
}

Susan A. Roces*

Raymond Tan

Francisco Jose T. Da Cruz

Shuren C. Gong

Rison K. Veracruz

Department of Chemical Engineering, College of Engineering, De La Salle University, 2401 Taft Ave., Malate, Manila 1004 Philippines

*e-mail: susan.roces@dlsu.edu.ph

Studies were carried out on the transesterification, also called methanolysis, of oil from the Jatropha curcas L. with methanol using conventional heating for the production of biodiesel. All reactions were carried out in a batch-stirred reactor and in the subsequent separation and purification stages.

The high free-fatty acid (FFA) level of Jatropha oil was reduced to less than $1 \%$ by a two-step process. The first step was carried out with $12 \% \mathrm{w} / \mathrm{w}$ methanol-to-oil ratio in the presence of $1 \% \mathrm{w} / \mathrm{w} \mathrm{HCl}$ as acid catalyst in a $2 \mathrm{~h}$ reaction at $343 \mathrm{~K}$. The second step was carried out with variable parameters: temperatures at $318 \mathrm{~K}$ and $333 \mathrm{~K}$, initial catalyst concentrations at $0.5 \%$ and $1.5 \%$, methanol:oil molar ratios at $4: 1$ and $6: 1$, and reaction times at $1 \mathrm{~h}$ and $2 \mathrm{~h}$. Gas chromatography analysis was used to determine the fatty acid profile of crude Jatropha oil. Methanolysis of Jatropha oil used the catalysts $\mathrm{NaOH}$ and $\mathrm{KOH}$.

The high FFA level of Jatropha oil was reduced from $6.1 \%$ to $0.7 \%$ after the first step process. The highest yield of fatty acid methyl esters (FAME), however, was achieved at $92.7 \%$ in $2 \mathrm{~h}$ at $4: 1$ methanol:oil molar ratio, $1.5 \% \mathrm{w} / \mathrm{w} \mathrm{KOH}$, and $333 \mathrm{~K}$ reaction temperature. This method produced biodiesel that met ASTM's biodiesel standards. Results showed a density of $0.8 \mathrm{~g} / \mathrm{ml}$ that is within $0.86-0.9 \mathrm{~kg} / \mathrm{l}$ standard range and a kinematic viscosity of about $4.1 \mathrm{cSt}$ that is within $2-4.5 \mathrm{cSt}$ standard range. The flash point of the biodiesel samples fell between $169^{\circ} \mathrm{C}$ and $179^{\circ} \mathrm{C}$ while the cloud point averaged at $6^{\circ} \mathrm{C}$.

Keywords: Jatropha curcas L., Methanolysis, Free Fatty Acid, Fatty Acid Methyl Ester, Biodiesel

\section{INTRODUCTION}

Fatty acid methyl esters (FAME) derived from renewable sources such as vegetable oils have gained importance as a substitute for petro-diesel to which it may be blended.

Numerous studies have been done 
using oils from such plants as the coconut, soybean, rapeseed, and palm. The main problem with many of these oils, however, is that they are edible oils and using them as source of alternative fuel will result in a competition with the food industries.

This problem can be overcome by using nonedible oilseed species—such as Jatropha (Jatropha curcas L.), Karanja (Pongamia pinnata), Mahua (Madhuca indica), Neem (Azadirachata indica), and Simarouba (Simarouba indica)-as alternative sources for the production of oil. Among these nonedible oils, the Jatropha curcas L. oil is one of the most promising.

Jatropha grows in many places and is found here in the Philippines, has a shorter gestation period, and can generate a high yield per hectare. Thus, the Philippine National Oil Company-Alternative Fuels Corporation (PNOC-AFC), which the Philippine government has tasked to take primary responsibility over the biofuels project, taps the qualities of the Jatropha as feedstock for its biodiesel production.

Transesterification is the reaction of an alcohol and an ester to form different alcohols and esters. In the production of biodiesel, vegetable oils are reacted with an alcohol in the presence of either a basic or an acidic catalyst. Hence, the process is called methanolysis when the alcohol used is methanol and ethanolysis when ethanol is used. The esters that form are called fatty acid methyl ester or FAME.

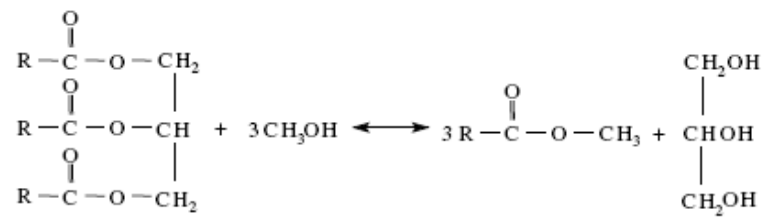

Figure 1. Transesterifcation of Triglyceride
The reaction scheme in Fig. 1 also produces glycerol, whose traditional applications are valuable in the pharmaceutical, cosmetics, and food industries, as byproduct.

The stoichiometry of reaction requires $3 \mathrm{~mol}$ of methanol and $1 \mathrm{~mol}$ of triglyceride to give $3 \mathrm{~mol}$ of FAME and $1 \mathrm{~mol}$ of glycerol. This leads to three consecutive reversible reactions where monoglyceride and diglyceride are intermediate products [1]. After the reaction, both the glycerol phase and the methyl ester phase are purified before the methyl ester is used as diesel fuel.

Attempts have been made to convert Jatropha oil into fatty acid methyl esters [2], [3], [4], [5]. The most recent of these studies were those done by Berchmans and Hirata in 2008 [6] that revealed maximum yields of methyl esters up to $90 \%$ with a molar ratio of $\mathrm{MeOH}$ :oil $0.24 \mathrm{w} / \mathrm{w}$ and $\mathrm{NaOH} 1.4 \% \mathrm{w} / \mathrm{w}$ of oil as catalyst when the reaction was conducted at $65^{\circ} \mathrm{C}$ for $2 \mathrm{~h}$. The study focused on the conventional method of producing FAME from Jatropha oil using the best combination of parameters to produce high yield of biodiesel.

\section{MATERIAL}

The Jatropha oil used in this study was purchased from Philforest.

\section{REACTION CONDITIONS}

The parameters used in the first step, referred to as the acid pretreatment, were adopted from Lu et al. [2] except for the acid catalyst. The experiments were carried out at constant $\mathrm{MeOH}$ : oil weight ratio at $12 \% \mathrm{w} / \mathrm{w}$, 
$\mathrm{HCl}$ :oil ratio at $1 \% \mathrm{w} / \mathrm{w}$, reaction temperature at $343 \mathrm{~K}$, and reaction time at 2h.

Parameters in the second step, for the methanolysis, had been varied for reaction time (1h and $2 \mathrm{~h}$ ), temperature (318K and $333 \mathrm{~K})$, percent weight of catalyst $(0.5 \% \mathrm{w} / \mathrm{w}$ and $1.5 \% \mathrm{w} / \mathrm{w}$ ), and $\mathrm{MeOH}$ :oil ratio (4:1 and 6:1). The catalysts chosen were $\mathrm{NaOH}$ and $\mathrm{KOH}$.

\section{APPARATUS}

The experimental setup had two main parts-the production setup and the settling setup - that were used in both acid pretreatment and biodiesel production.

The production setup consisted of a tightly sealed glass bottle and a thermostatic bath. The glass bottle had a capacity of $150 \mathrm{ml}$ and the thermostatic bath was set to $140 \mathrm{rpm}$, with the temperature also adjustable. The settling setup consisted of an iron stand, an iron clamp, and a separatory funnel. The separatory funnel was clamped to the iron stand, leveled horizontally with the nose of the funnel facing downwards.

\section{EXPERIMENTAL}

\section{Acid Pretreatment}

The parameters were held constant with $\mathrm{MeOH}$ :oil weight ratio at $12 \% \mathrm{w} / \mathrm{w}, \mathrm{HCl}$ :oil ratio at $1 \% \mathrm{w} / \mathrm{w}$, reaction temperature at $343 \mathrm{~K}$, and reaction time at $2 \mathrm{~h}$.

Oil batches of $30 \mathrm{~g}$ each were made to which $3.6 \mathrm{~g}$ of $\mathrm{MeOH}$ and $0.3 \mathrm{~g}$ of the acid catalyst $\mathrm{HCl}$, and then heated at $70^{\circ} \mathrm{C}$ for $2 \mathrm{~h}$. The thermostatic bath was set to 140rpm for the duration of the process.
The product was then left to settle overnight, after which the lower catalyst-rich layer was discarded. The product was then washed twice with distilled water to remove excess catalyst and left to settle until the two layers had mostly separated. The lower layer was discarded.

\section{Transesterification}

Parameters in the methanolysis had been varied for reaction time ( 1 hour and 2 hours), temperature (318K and 333K), percent weight of catalyst $(0.5 \% \mathrm{w} / \mathrm{w}$ and $1.5 \% \mathrm{w} / \mathrm{w}), \mathrm{MeOH}$ :oil ratio (4:1 and 6:1), and catalyst $(\mathrm{NaOH}$ and $\mathrm{KOH})$.

A solution of $1 \mathrm{M}$ base catalyst was prepared by dissolving the catalyst either $\mathrm{KOH}$ and $\mathrm{NaOH}$ in a beaker with methanol. The resulting mixture was transferred into the reactor with $20 \mathrm{ml}$ aliquots of esterified oil. This mixture was placed in a thermostatic bath set to 140rpm for the required number of hours at the designated temperatures.

Then, the mixtures were allowed to settle overnight in a separatory funnel. The lower glycerol-rich layer was removed; and, the upper biodiesel-rich layer was collected and stored for further testing.

\section{ANALYTICAL METHODS}

\section{Characterization Jatropha Oil}

Oil quality determined how the experiments should proceed; therefore, before any experiment could be done, the oil would have to be classified accurately first.

Thus, for the present study, the mixture was tested for its acid value and free fatty acid value using ASTM D1193.

The fatty acid profile was obtained 
through gas chromatography, which was conducted by the Department of Science and Technology (DOST).

Likewise, the moisture content and saponification number of the raw oil were likewise identified.

\section{Determination of Biodiesel Properties}

Properties of methyl esters-for example, density, kinematic viscosity, flash point, and cloud point-were determined using applicable procedure.

\section{Determination of Percent Yield}

The percent yield of biodiesel was based on the weight of the glycerol obtained, with $90 \%$ purity as noted by K. Addison [7], given the following equation:

$\%$ yield $=\frac{0.9\left(W_{\text {glycerol }}\right)\left(\frac{M W_{\text {FAME }}}{M W_{\text {glycerol }}}\right)}{W_{\text {initial }}} \times 100 \%$

where:

$$
\begin{aligned}
W_{\text {glycerol }}= & \text { weight of glycerol } \\
M W_{F A M E}= & \text { molecular weight of FAME, } \\
& 889 \frac{\mathrm{gm}}{\text { gm-mole }} \\
M W_{\text {glycerol }}= & \text { Molecular weight of } \\
& \text { glycerol, } 92.01 \frac{\mathrm{gm}}{\mathrm{gm-mole}}
\end{aligned}
$$

\section{RESULTS AND DISCUSSION}

\section{Molecular Weight of Jatropha Oil}

The fatty acid profile of Jatropha oil is given in Table 1.

Table 1. Fatty Acid Profile of Jatropha Oil

\begin{tabular}{cccc}
\hline $\begin{array}{c}\text { Fatty } \\
\text { Acids }\end{array}$ & $\begin{array}{c}\text { Chemical } \\
\text { Formula }\end{array}$ & $\begin{array}{c}\text { w/w } \\
\mathbf{( \% )}\end{array}$ & $\begin{array}{c}\text { Molecular } \\
\text { Weights }\end{array}$ \\
\hline Palmitoleic & C16:1 & 15.4 & 238.46 \\
Heptanoic & C17:1 & 1.56 & 254.52 \\
Oleic & C18:1 & 9.98 & 268.54 \\
Linoleic & C18:2 & 39.8 & 266.52 \\
Nonanoic & C19:0 & 33.3 & 282.57 \\
\hline
\end{tabular}

The molecular weight of the Jatropha oil was computed at $889 \mathrm{~g} / \mathrm{g}-\mathrm{mol}$. This value was comparable to the $882.93 \mathrm{~g} / \mathrm{g}$-mol given in B. A. C. Chan et al. [8].

\section{Characterization of Jatropha Oil}

The weight of the oil did not change when it was heated to $105^{\circ} \mathrm{C}$ for $1 \mathrm{~h}$. This meant that the oil had no moisture content.

The results of the acid pretreatment process are shown in Table 2.

Table 2. Acid and FFA Values of Jatropha Oil, before and after Acid Pretreatment

\begin{tabular}{ccc}
\hline & $\begin{array}{c}\text { Initial } \\
\text { Value }\end{array}$ & $\begin{array}{c}\text { Final } \\
\text { Value }\end{array}$ \\
\hline $\begin{array}{c}\text { Acid Value } \\
\text { (mg KOH/g oil) } \\
\text { FFA } \\
(\% \mathrm{w} / \mathrm{w})\end{array}$ & 12.7 & 1.5 \\
\hline
\end{tabular}

Reduction of the \% FFA to below $1 \%$ was achieved using a two-stage pretreatment method. Lowering the FFA level from 6.1\% to $0.7 \%$ had been an acceptable value before the transesterification process.

The saponification number of the sample was calculated at $199.10 \mathrm{mg} \mathrm{KOH} / \mathrm{g}$ oil, which was within the $185-210 \mathrm{mg} \mathrm{KOH} / \mathrm{g}$ oil range for Jatropha oil.

\section{Transesterification Results}

Trial runs performed using the catalysts $\mathrm{NaOH}$ and $\mathrm{KOH}$, revealed $\mathrm{NaOH}$ to be undesirable for the purpose.

Using even a small amount of $\mathrm{NaOH}$ as catalyst resulted in a significant amount of soaping. Also, using $\mathrm{NaOH}$ tended to form solids mainly on the glycerol byproduct when no soap formation appeared when $\mathrm{KOH}$ was used as catalyst.

Thus, $\mathrm{NaOH}$ was not used further for the 
duration of the experiments.

The percent yields of biodiesel produced with the variable parameters are given in Table 3. This was based on the weight of the glycerol measured after the transesterification process using $\mathrm{KOH}$ as catalyst.

Table 3. Experimental Results on Percent Yield Biodiesel

\begin{tabular}{cccccc}
\hline & $\begin{array}{c}\text { Time } \\
\text { (h) }\end{array}$ & $\begin{array}{c}\text { MeOH:Oil } \\
\text { Ratio }\end{array}$ & $\begin{array}{c}\text { KOH } \\
(\% \mathbf{w} / \mathbf{w})\end{array}$ & $\begin{array}{c}\text { Temp } \\
\left({ }^{\circ} \mathbf{C}\right)\end{array}$ & $\begin{array}{c}\text { Yield } \\
(\%)\end{array}$ \\
\hline 1 & 1 & $4: 1$ & 0.5 & 45 & 48.7 \\
2 & 2 & $4: 1$ & 0.5 & 45 & 56.8 \\
3 & 1 & $4: 1$ & 1.5 & 45 & 77.3 \\
4 & 2 & $4: 1$ & 1.5 & 45 & 85.2 \\
5 & 1 & $6: 1$ & 0.5 & 45 & 52.9 \\
6 & 2 & $6: 1$ & 0.5 & 45 & 54.8 \\
7 & 1 & $6: 1$ & 1.5 & 45 & 86.5 \\
8 & 2 & $6: 1$ & 1.5 & 45 & 87.0 \\
9 & 1 & $4: 1$ & 0.5 & 60 & 57.2 \\
10 & 2 & $4: 1$ & 0.5 & 60 & 61.4 \\
11 & 1 & $4: 1$ & 1.5 & 60 & 90.4 \\
12 & 2 & $4: 1$ & 1.5 & 60 & 92.7 \\
13 & 1 & $6: 1$ & 1.5 & 60 & 90.3 \\
14 & 2 & $6: 1$ & 1.5 & 60 & 92.3 \\
\hline
\end{tabular}

It was observed that increasing the molar ratio of $\mathrm{MeOH}$ to oil from 4:1 to 6:1 showed slight improvement on all samples except for samples 2, 6, 11, and 13. Sample 6, which had a 6:1 ratio, showed a decrease in \% yield as compared to sample 2, which had a 4:1 ratio. Samples 11 and 13 had the same parameters, except for their $\mathrm{MeOH}$ :oil ratio, and showed practically the same yield.

The effect of molar ratio showed that yield increased slightly as molar ratio increased. Some samples, however, either showed a decrease in \% yield or no change in \% yield.

Similarly, increasing the reaction time showed very slight increase in most of the samples. This result meant that an hour of reaction time was enough to produce a high yield of biodiesel.

The most effective parameter had been the amount of catalyst used as noted in the study by Y. Rathana et al. [9]. The yields increased from $50 \%$ to $60 \%$ using $0.5 \%$ catalyst and from $80 \%$ to $100 \%$ using $1.5 \%$ catalyst.

Temperature was found to be the second most significant parameter, next to catalyst amount. Using higher temperatures in biodiesel production generally resulted in higher yields.

\section{Biodiesel Properties}

Some of the properties of the biodiesel produced in reactions using $\mathrm{KOH}$ catalyst are listed in Table 4. These properties were compared with those given in the Philippine National Standards for Biodiesel (PNS) [10].

Table 4. Properties of Biodiesel Produced

\begin{tabular}{lcc}
\hline \multicolumn{1}{c}{ Properties } & PNS & Biodiesel \\
\hline Density $(\mathrm{kg} / \mathrm{l})$ & $0.86-0.90$ & 0.87 \\
Kinematic Viscosity & $2.0-4.5$ & 4.1 \\
$@ 40^{\circ} \mathrm{C}(\mathrm{cSt})$ & & \\
Flash Point $\left({ }^{\circ} \mathrm{C}\right)$ & Min. 100 & 175 \\
Cloud Point $\left({ }^{\circ} \mathrm{C}\right)$ & Report & 6 \\
\hline
\end{tabular}

The initial density of the oil was $0.914 \mathrm{~kg} / \mathrm{l}$ while the average density of the biodiesel produced was observed at around $0.87 \mathrm{~kg} / \mathrm{l}$ for all samples.

Sample 1, however, gave the highest density at $0.8942 \mathrm{~kg} / \mathrm{l}$. This value revealed that it had been the most unreacted of all the samples, having used the least amount of catalyst and methanol.

It was noted, too, that sample 1 had the least desirable parameters among the samples that were studied. Similar to the 
data for biodiesel density when the transesterification process had been done properly, the result for kinematic viscosity would be within the acceptable range as shown in Table 4.

The $175^{\circ} \mathrm{C}$ average flash point obtained for majority of the biodiesel samples was well within the $100^{\circ} \mathrm{C}$ minimum standard value set by the PNS. On the other hand, the $6^{\circ} \mathrm{C}$ average cloud point revealed that the kind of biodiesel produced could be used in both tropical and temperate climates.

\section{CONCLUSIONS}

Based on experimental data and results, the most desirable set of parameters for the transesterification of oil from the Jatropha curcas L. has more catalyst at higher temperature and reaction time with less or just the right amount of alcohol.

Therefore, a $1.5 \%$ amount of catalyst at a temperature of $373 \mathrm{~K}$ and a reaction time of $2 \mathrm{~h}$ with the alcohol ratio at $4: 1$ is most suitable for the production of biodiesel.

For these parameters, the highest yield achieved had been $92.7 \%$ for biodiesel whose properties conformed to those set by the Philippine National Standards for Biodiesel (PNS).

These results suggest that further improvement in biodiesel yield may be achieved using other catalysts like as sodium methoxide and other homogeneous bases, heterogeneous base catalysts, or enzymes.

\section{Acknowledgment}

The authors express their gratitude to Dr. Nathaniel Dugos and Dr. Florinda Bacani for their insights and knowledge on various matters that concern our research work.

\section{REFERENCES}

1) G. Vicente, M. Martinez, and J. Aracil: Bioresource Technology 92(2004): 297-305.

2) H. Lu, Y. Liu, H. Zhou, Y. Yang, M. Chen, and B. Liang: Computers and Chemical Engineering 33(2008): 1091-1096.

3) S. Shah and M. N. Gupta: Process Biochemistry 42(2007): 409-414.

4) N. O. Tapanes, D. G. Aranda, J. M. Carneiro, and O. C. Antunes: Fuel 87(2008): 2286-2295.

5) A. K. Tiwari, A. Kumar, and H. Raheman: Biomass and Bioenergy 9(2007): 569-575.

6) H. J. Berchmans and S. Hirata: Bioresource Technology 99(2008): 1716-1721.

7) K. Addison, 2006 (URL: http://www.journeytoforever.org/biodies el glycsep.htm1 Date Accessed: 18 May 2009)

8) B. A. C. Chan, L. A. C. Chua, M. B. Eliseeff, and S. A. Roces: Proceedings of ST (2009).

9) Y. Rathana, S. A. Roces, F. T. Bacani, R. R. Tan, M. Kubouchi, and P. Yimsiri: International Journal of Chemical Reactor Engineering 8(2009): S5.

10) DPNS/DOE QS 002:2007. (URL: http://www.doe.gov.ph/popup/dpns Date Accessed: 8 March 2008) 